\title{
HOUSEHOLDS TRAVEL BEHAVIOUR TO MARKETS IN RURAL COMMUNITIES IN AYEDAADE LOCAL GOVERNMENT AREA OF OSUN STATE, NIGERIA
}

\author{
Musilimu Adeyinka Adetunji \\ Department of Geography, Faculty of Social Science, Federal University Lokoja, Kogi State, \\ Nigeria \\ E-mail: musilimuadetunji@yahoo.com
}

Citation: Adetunji, M.A. 2020. Travel Behaviour of Women to Markets in Rural Communities in Ayedaade Local Government Area of Osun State, Nigeria. J. Asian Rur. Stud, 4(2): 202217

\begin{abstract}
Many rural households in Nigeria are less accessible to markets to transact their business. Traders travel considerable distance and pay high transport fare to convey their goods to markets for sale. This is because many rural communities are located farther away from where the markets are situated. It is on this background that this study examined the accessibility of traders to markets in some rural communities in Ayedaade Local Government Area of Osun State. Both primary and secondary data were utilized for this research. Three sets of data were required. The first set of data focused on the socio-economic characteristics of traders such as gender classification, family composition, level of education and possession of personal means of transportation. The second data required focused on the travel pattern of rural population to markets taking into account attributes such as distance travelled, mode of transportation mostly used, average travel time and frequency of trip to market in a week. The last category of data elicited was based on constraint of women to access market centres in the region. Descriptive and inferential statistics were employed to analyse the data. Findings reveal that the pattern of distribution of markets is in the study area is dispersed rather than random. Agricultural products and few manufactured goods are traded at Olufi central market in the study area. More than $60 \%$ of traders relied on Public transport (motorcycle), which charge exorbitant transport fare to convey their goods to markets. Arrays of goods traded in the market is the first major determinant factor affecting the markets patronized by traders in the council area and this accounts for about $17.53 \%$ of the total explained variance of the factor analysis. The study therefore recommends that there is need to provide community based transport services at subsidized rate for rural communities in Nigeria so as to enhance the accessibility of women to markets and participate in other productive activities in the rural areas of Nigeria.
\end{abstract}

Keywords: Women; Accessibility; Development; Government; Planning

\section{Introduction}

Women generally have less access to transport services so as to engage in different trip purposes such as work, shopping, recreation and visit to relatives when occasions demand. The situation is much complex in some rural communities in Nigeria where millions of women reside to earn their livelihood. Many rural dwellers in Nigeria do not have their own personal means of transportation, they rely more on public transport 
services which are not easily accessible (Dawson and Barwell 1993; Ellis, 1996 as cited in Starkey, Ellis, Hine, Ternell, 2002: p. 10). On a general note, men tend to monopolize transport services available to members of their families at the expense of the women (Pucher, 2009: p.5 as cited in Deike, 2013: p5). Since time immemorial, no community has been self- sustaining, they rely on others for the goods they cannot produce, hence, there is need for exchange of goods and this is better done at the market centre where buying and selling takes place. Women are at the centre of such transactions in Nigeria. It is pertinent to note that majority of women in rural communities in Nigeria convey by head agricultural produce to markets for sale, and trekking several kilometres (Adetunji, 2003: p.1). Studies have shown that women play a significant role in rural development in Nigeria and elsewhere particularly when it comes to the issues of production of foods and other domestic activities (Ejembi; Obekpa. Ivande, 2017: p. 146). The author advocates that women should be given chance to participate in the management of rural resource so as to promote the level of development in the rural communities in Nigeria and other Sub Saharan African countries.

In an assessment of the accessibility of women to market in Pune, India, Astrop; Palmer; Maunder and Babu (1996: 29), reported that distance to the trading point and convenience are the main reasons for trading in the particular market in the study area. They reported that many respondents tend to trade within local areas and commute short distance to market. More than $50 \%$ of market women in Pune, India indicated that they travelled by foot. The frequency of their trip to market is a function of the nature of rural road network, demand and distance travelled (Ellis, 1998; Adetunji, 2003: 44). In some of the rural communities in Sub-Saharan countries, many traders travel to periodic market in order to buy or sell goods. Market is seen as central or meeting place where traders from rural or urban centres meet to engage in their business transactions. Despite the role of rural market in facilitating social, cultural and economic development of their environment, it is pertinent to note that high transport fare charge by vehicle owners, long distance travel, unreliable transport services and poor rural network are some of the major challenges to access rural markets in Nigeria. It is on this background that this study was designed to examine the accessibility of traders (men and mostly women) to markets in some rural communities in Ayedaade Local Government Area of Osun State so as to advise the government on how to alleviate transport challenges of traders in the region and other agrarian communities in Nigeria in general.

\section{Theoretical Point of Departure}

Theoretically, a market serves as a central place to the surrounding rural settlements. It provides essential goods and services to the neighbouring towns and villages (Dey; Pathak; Baghmar, 2017: p.45. In this context, manufactured goods produced in the towns are brought to the rural markets for sale. Similarly, agricultural produce in villages such as yams, banana, tomatoes, pepper to mention but few are traded at the local market. The exchange of goods at the market helps to promote social interaction in the environment and promote cultural and economic development of the region. This help to alleviate the poverty of rural dwellers because it gives opportunity to the farmers to get market for their farm produce and reduce wastage that might result from rotten food items on their farm sites (Dey; Pathak; Baghmar, 2017: p.45). Despite the 
significant role of market for economic, social and regional development, it is worrisome to observe that many rural dwellers particularly women and their children in Nigeria are less accessible to market due to poor rural road networks and unreliable transport services. The situation is more complex in Ayedaade Local Government Area of Osun State, where some of these roads are in deplorable conditions. Motorized transport services particularly Pick Up Vans which were easily accessible for rural mobility in the early 90s are no long available except in few rural communities connected to all weather roads. It is on this background that this study aims to examine travel behaviour of women to market in Ayedaade Local Government Area of Osun State with a view to promoting the accessibility of traders to market and encourage farmers to produce more of agricultural goods for marketing in the region.

\section{The Study Area}

Ayeedaade Local Government Area of Osun State is the study area (See Figure 1). Virtually all settlements in Ayedaade Local Government of Osun State are rural communities except Gbongan, Odeomu and Orile - Owu. The study area lies within the tropical rainforest, where agriculture is the main occupation of the inhabitants due to the favourable climatic condition of the region. Farmers in this local government cultivate food crops for domestic consumption and excess produce for sale at the local markets. The food crops cultivated in the council area include yam, maize, banana, plantain, cassava and many other local food crops. Cocoa is the principal export crop produced in the rural regions of the study area. Large production of agricultural crops has promoted the image of Ayedaade Local Government area in the south-western Nigeria as one the trading centres for agricultural products. Before independence, many periodic markets sprang up in some of the rural communities in Ayedaade Local Government Area to facilitate the marketing of their agricultural products. Some of these notable markets are Olufi market which is located at Gbongan, the head Quarters of Ayedadde Local Government. Other prominent markets in the region include Obada located at Odeomu town, Akiriboto, Araromi Owu and Wakajaiye (Figure 1). Apart from agricultural products produced in the region, manufactured goods of various types are brought from many states of the federation for trading purposes. It is on this background that this study aims to examine the pattern of trading activities in the region with the specific objective of examining the constraint of women to achieve a sustainable business activity or trading activity in the region. 


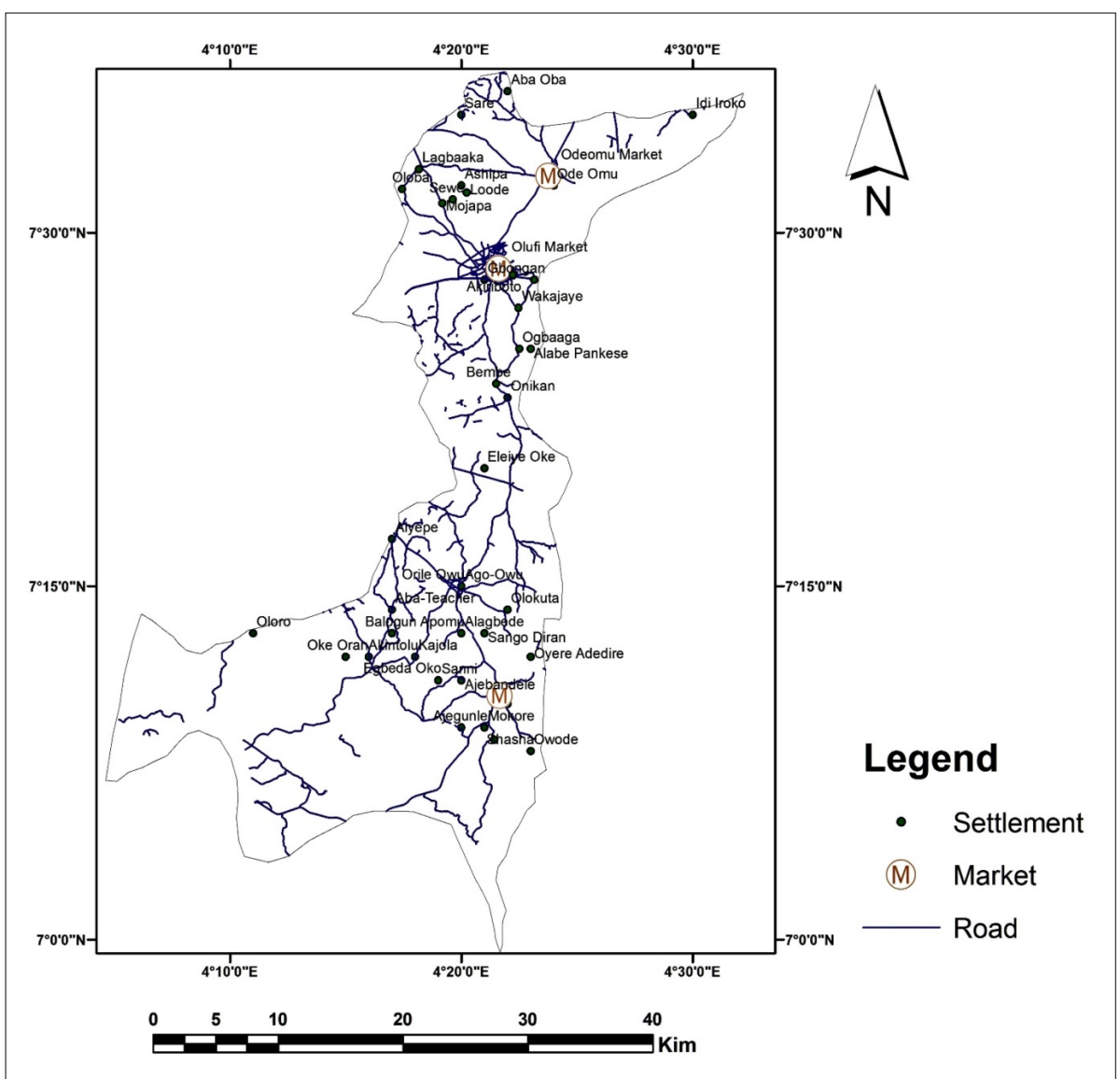

Figure 1: Selected Rural Settlements and Major Functioning Markets in Ayedaade Local Government Area of Osun State.

\section{Method}

\subsection{Materials}

Primary and secondary data were utilized for this research. Primary data comprises of three categories. The first set of data focused on the socio-economic characteristics of rural dwellers with emphasis on gender composition, level of education, occupation and possession of personal means of transportation. The second data required focus on the travel pattern of rural population to markets taking into account attributes such as distance travelled, mode of transportation mostly used, average travel time and frequency of trips to the market in a week. The last category of data solicited was based on constraint of women to access market centres in the region particularly on their issues of accessing personal mean of transportation, movement of their goods on poor rural roads that were largely untarred.

The secondary data utilised include an administrative map of Ayedaade Local Government Area made available by Ayedaade Local Government Council Area of Osun State. Other data were the coordinates of (i) selected rural settlements that have a population of less than 500 in the Council Area. (ii) Main Existing markets patronized by rural households in the study area, using a hand held Geographical Position System (GPS). These coordinates were subsequently plotted to produce point maps using the UTM, Zone 31, Minna datum coordinate system. The point maps produced were overlaid on the scanned administrative map which was used to produce (i) Map showing 
the locations of main market patronized by rural households in the study area. The average distance of the nearest Main market to each of the sampled rural settlements in Ayedaade Local Government Area was measured using the 'Ruler' menu of ArcGIS 10.3.1. Furthermore average nearest neighbourhood analysis was performed for the point data using the Spatial Statistics toolbox of ArcGis 10.3.1 software.

\subsection{Method}

Thirteen rural settlements with population of less than 5,000 were purposefully selected for questionnaire administration. An average of 20 traders was selected in each of the sampled settlement. A systematic random sampling procedure was adopted in the administration of these questionnaires in the selected villages to the trader in respect of their gender classification. A systematic random sampling procedure was based on the principle that once the initial trader of 1 in every 3 building was selected, others subsequently follow in a sequential or regular pattern until 20 copies of questionnaire was completed in each of the sampled settlement. On the whole, 260 copies of questionnaires were administered, out of which 202 were analyzable.

\subsection{Statistical Analysis}

Both descriptive and inferential statistics were employed to analyze the data. Descriptive statistics utilized include tables of percentage to analyses the travel patterns of rural traders to markets. Analysis of Variance was used to examine the variation in mode choice of transportation among sampled rural household to markets. Average Nearest Neighbourhood Analysis was used to examine the average distance of the nearest Main market to each of the sampled rural settlements in the study area. Factors Analysis was employed to determine most significant factors affecting the markets patronized by traders in agrarian communities of Ayedaade Local Government Area of Osun State.

\section{Results and Discussion}

\subsection{Rural Roads Characteristics in the Study Area}

Many rural road networks in Nigeria are in deplorable conditions. Some rural communities are less accessible to some basic facilities located outside their village. Ayedaade Local Government Area of Osun State is not exempted from this menace. Table 1 reveals that $60.0 \%$ of rural communities sampled in the council area are connected with earth surface rural road that was largely untarred. These communities are Bembe, Lagbaka, Mojapa, Oloba and Oluwada. Apart from the fact that these villages are one lane, some are not motorable during the rainy season. Traders in these communities have access to only commercial motorcycles to transport their goods on the market day. Further analysis reveals that the maintenance culture of rural road networks in the study area require much to desire. Table 1 show that $13.8 \%$ of the traders in rural communities sampled in the council area indicated that the road network connecting their villages have never been rehabilitated or maintained over the past twenty years. $86.1 \%$ of rural households in the study area indicated that road networks connecting their villages experienced rehabilitation within the last five years. This contrary to what exists in Asian countries where (Donnges; Edmonds; Johannessen, 
2007) have reported that routine maintenance of rural road networks is highly essential to enhance accessibility of people to markets and other activity centres located in the neighbouring communities.

Table 1: Rural Roads Characteristics in Ayedaade Local Government Area of Osun State

\begin{tabular}{|c|c|c|c|c|c|c|}
\hline \multirow[t]{2}{*}{$\begin{array}{c}\text { Name of Settlement } \\
\text { or village }\end{array}$} & \multicolumn{2}{|c|}{$\begin{array}{c}\text { Nature of road networks connecting } \\
\text { Sampled villages to the Market } \\
\text { Patronised }\end{array}$} & \multirow[t]{2}{*}{ Total } & \multicolumn{2}{|c|}{$\begin{array}{l}\text { How often is the road } \\
\text { maintained }\end{array}$} & \multirow[t]{2}{*}{ Total } \\
\hline & Tarred road & Untarred road & & Never & Periodically & \\
\hline AKIRIBOT & 0 & 15 & 15 & 0 & 15 & 15 \\
\hline ALABE PA & 0 & 15 & 15 & 0 & 15 & 15 \\
\hline BENBE & 14 & 0 & 14 & 0 & 14 & 14 \\
\hline LAGBAKA & 16 & 0 & 16 & 0 & 16 & 16 \\
\hline LOODE & 0 & 16 & 16 & 6 & 10 & 16 \\
\hline MOJAPA & 17 & 0 & 17 & 6 & 11 & 17 \\
\hline MOKORE & 0 & 15 & 15 & 0 & 15 & 15 \\
\hline OGBAAGA & 0 & 15 & 15 & 0 & 15 & 15 \\
\hline OLOBA & 16 & 0 & 16 & 16 & 0 & 16 \\
\hline OLUWADA & 17 & 0 & 17 & 0 & 17 & 17 \\
\hline SARE & 0 & 15 & 15 & 0 & 15 & 15 \\
\hline SEWE & 0 & 16 & 16 & 0 & 16 & 16 \\
\hline WAKAJAYE & 0 & 15 & 15 & 0 & 15 & 15 \\
\hline Total & $80(39.6)$ & $122(60.6)$ & 202 & $28(13)$. & $174(86.1)$ & 202 \\
\hline
\end{tabular}

Source: Author's Field Survey, 2019

\subsection{Periodic Markets Patronized}

Finding reveals that there are eight periodic markets in Ayedaade Local Government area of Osun state. Some of these markets are Olufi, Oloba, Lagbaka, Onimu, Akiriboto 1, Akiriboto 11, Odeomu popularly called Obada market and Araromi Owu market. Due to rural urban migration in the early $80 \mathrm{~s}$, only three markets are functioning at the study area. These markets are Olufi main market, Obada market and Araromi market. In terms of the market patronage by traders either within or outside the local government area, Olufi is ranked highest. Table 2 revealed that $89.6 \%$ of the traders patronized Olufi market to transact their business. $7.4 \%$ of traders indicated that they travelled to Araromi market. Only 3.0\% travelled to Odeyinka market which is located at the neighbouring local government of the state. The result of this analysis is tangential or similar to the study of the urban travel behaviour and constraints of low income households and females in Pune, India, where Astrop, Palmer, Maunder and Babu (1996: p.29), reported that distance to the point of trading and convenience are major factors considered by traders in their choice of market for transaction of their business. Different varieties of goods are traded in the market in the council area. Table 2 revealed that agricultural products accounted for $88 \%$ of goods traded in the markets. Some of these agricultural products are banana, yam, pepper, onion, poultry products and beans. Beverages such as bournvita, toiletries and cosmetics are ranked second $(5.0 \%)$ among the products traded in the markets in the study area. Building materials, textile products and agricultural implements such as cutlass and chemicals constituted $3.0 ; 2.5 \%$ and $1.4 \%$ respectively. A substantial proportion of goods traded in the market in the study area come principally from within the Local Government Area. Table 2 revealed that $67.3 \%$ of the products traded in the markets comes from rural communities in Ayedaade Local Government. The remaining $32.7 \%$ of the goods traded in the market come from other parts of the country. In many rural communities in 
Nigeria, women are generally responsible for the movement of agricultural products to the market. Table 1 revealed that $75.8 \%$ of women in Ayedaade Local Government area of Osun state convey agricultural products to the market. Another $10.2 \%$ of their female children assist their parents to transport their farm produce to the market for sale. Only $7 \%$ each of men and their male children were involved in the movement of farm products to the market. It can be deduced from this analysis that the role of women in rural development particularly in the area of trading activities in rural communities cannot be undermined. The results of this analysis is similar to study carried out in Benue State in Nigeria, where (Ejembi; Obekpa. Ivande, 2017: p. 150), reported that women and their children are assigned the responsibility of gathering non-timber produce for onward transportation to market for sale.

Table 2: Characteristics of Periodic Market Patronized by Traders in the Study Area

\begin{tabular}{|c|c|c|}
\hline Variables & Frequency & Percentage \\
\hline \multicolumn{3}{|l|}{ Name of the Market Patronised } \\
\hline Araromi- Orile-Owu & 15 & 7.4 \\
\hline Odeyinka(Ireeole LGA) & 6 & 3.0 \\
\hline Olufi-Gbonga & 181 & 89.6 \\
\hline Total & 202 & 100.0 \\
\hline \multicolumn{3}{|l|}{ Goods Traded in the Market } \\
\hline Agricultural Products & 178 & 88.0 \\
\hline Textile Products & 5 & 2.5 \\
\hline Agricultural Implement & 3 & 1.4 \\
\hline Building Materials & 6 & 3.0 \\
\hline Provision & 10 & 5.5 \\
\hline Total & 202 & 100.0 \\
\hline \multicolumn{3}{|c|}{ Sources of Goods Traded in the Market } \\
\hline Produced within the LGA & 136 & 67.3 \\
\hline Produced outside the & 36 & 32.7 \\
\hline Total & 202 & 100.0 \\
\hline \multicolumn{3}{|c|}{$\begin{array}{l}\text { Household Member Responsible for the Movement of } \\
\text { Agricultural Products to the Market }\end{array}$} \\
\hline Father(Men) & 9 & 7.0 \\
\hline Mother(Women) & 97 & 75.8 \\
\hline Male Children & 9 & 7.0 \\
\hline Female Children & 13 & 10.2 \\
\hline Total & 128 & 100 \\
\hline
\end{tabular}

Source: Author's Field Survey, 2019

\subsection{Market Patronized by Traders in the Study Area}

Several reasons were given by traders/ market women for patronizing a particular market in the study area; some of these reasons specified include short distances from their villages to the market, centrality and easy access to sell their products, as well as demand for their products. Above all, distance to the market and accessibility was ranked highest by majority of the traders. The mean distance travel from the sampled settlements to Olufi market is $8.85 \mathrm{~km}$. This ranged from $1.3 \mathrm{~km}$ in Akiriboto to $9.8 \mathrm{~km}$ 
in Oloba village. Traders living at Bembe, Oloba, Mojapa, Sewe and Mokore are less accessible to Olufi market because they travelled more than $6 \mathrm{kms}$ on rural road to engage in their business transactions during the market day. Obada market located in Odeomu town is the next periodic market patronized by traders in the study area after Olufi market. The mean distance travelled to access this market by the residents of these villages is $13.5 \mathrm{~km}$. Table 3 reveals that villagers from Mokore, Wakajaye, ,Bembe, Oloba and Lagbaka travelled more than $10 \mathrm{~km}$ to access Obada market at Odeomu. Long distance travel to market by traders in many villages sampled to engage in business transaction implies that traders in the study area are less accessible to market. This is because the commuting distance to markets is more than $10 \mathrm{~km}$ radius recommended for maximum distance travelled to access rural market (Tracy-White, 1995). Araromi Owu market in Ayedaade Local Government Area and Odeyinka market located at Irewole Local Government are the least periodic markets patronized by traders from the study area. These two markets are located farther away from some of the rural communities in Gbongan and Odeomu, which constitutes two out of three major regions where the council area are divided to. Only traders in Mokore village are more accessible to Ararom market and they travel at an average of $3.5 \mathrm{~km}$ to the market. Other sampled settlements travel more than $20 \mathrm{~km}$ to transact their businesses at Araromi Owu market. However, some other settlements located close to Orile Owu town are more likely to travel short distances to access this market.

Table 3: Mean Distance Travelled to Market

\begin{tabular}{lccc}
\hline \multicolumn{1}{c}{ Settlement Name } & Olufi Market & Odeomu (Obada) Market & Araromi Owu Market \\
\hline Mojapa & $\mathbf{6 . 7}$ & $\mathbf{8 . 7}$ & $\mathbf{3 8 . 7}$ \\
\hline Sewe & $\mathbf{6 . 5}$ & $\mathbf{7 . 8}$ & $\mathbf{3 8 . 9}$ \\
\hline Loode & 6.4 & 6.7 & 39.4 \\
\hline Lagbaaka & 10 & 10.3 & 41.7 \\
\hline Oloba & 9.8 & 11.7 & 40.4 \\
\hline Akiriboto & 1.3 & 8.3 & 32.9 \\
\hline Alabe Pankese & 6.5 & 13.7 & 27.2 \\
\hline Ogbaagba & 6.5 & 8.1 & 27.1 \\
\hline Wakajaye & 3.5 & 10.6 & 30.4 \\
\hline Bembe & 9.5 & 16.8 & 24.4 \\
\hline Mokore & 36.9 & 44.2 & 3.5 \\
\hline \multicolumn{1}{c}{ Average Distance } & 8.85 & 13.5 & 31.4 \\
\hline Author's Computation: 2019 & & &
\end{tabular}

\subsection{Results of Analysis of Variance on Average Distance Travel to the Nearest Market}

In order to determine the average distance of the nearest main market to each of the sampled rural settlements in Ayedaade Local Government Area, using the 'Ruler' menu of ArcGIS 10.3.1, the result of Average Nearest Neighbourhood Analysis reveals that the Observed Mean Distance to access market patronized is 16635 metre, compared to Expected Mean Distance travel of: 3323.4089 metre. The pattern of distribution of existing markets patronized by rural households in Table 4 shows that it is dispersed rather than random distribution. This implies that rural households in Ayedaade Local Government Area of Osun State would travel considerable distance to access market to trade their goods. Given the Z-Score of 13.2721, there is less than $1 \%$ likelihood that this dispersed pattern could be the result of random chance. The result of this analysis is tangential to the study of the (socio-economic facility), particularly distribution 
pattern and accessibility of students to secondary educational facilities in Lokoja, in north central Nigeria, where Adetunji (2018) reported that inadequate provision of secondary educational facilities had resulted to long distance commuting by those residents where such facility is lacking.

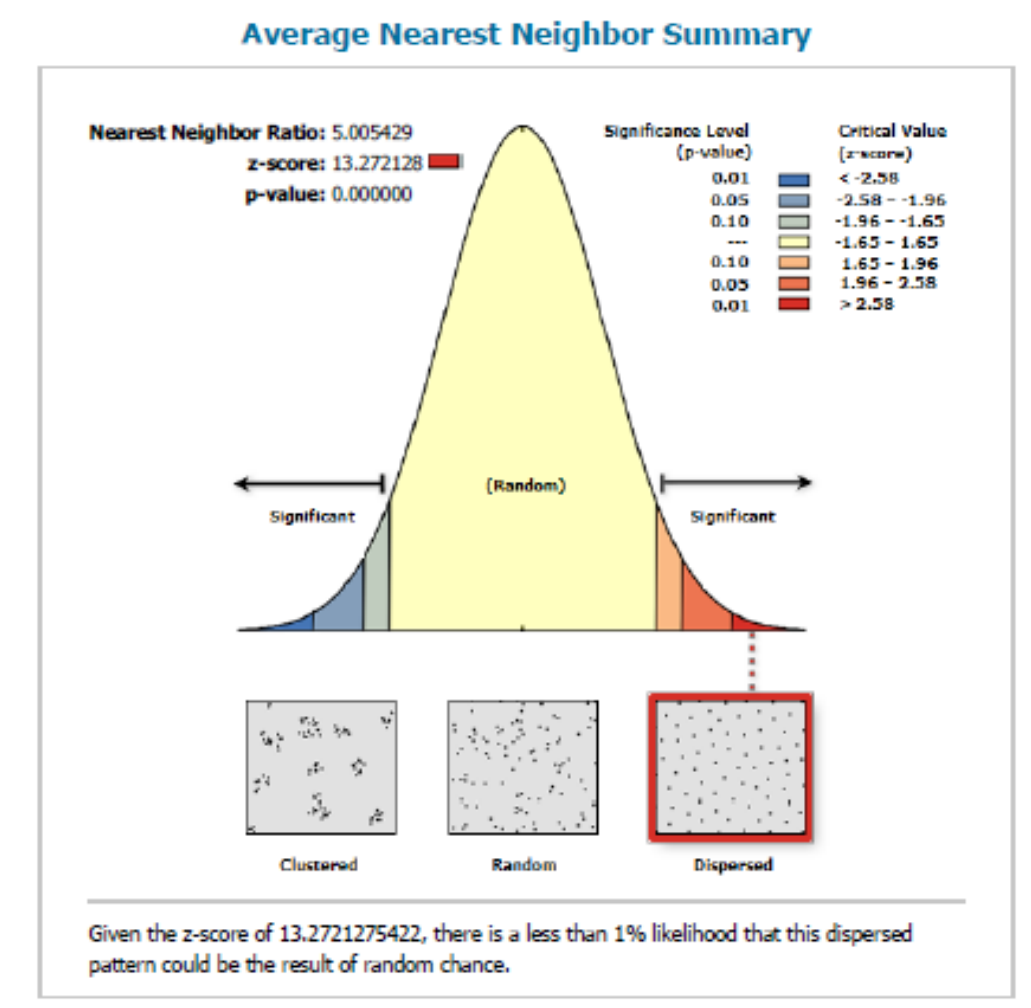

\begin{tabular}{|r|l|}
\hline \multicolumn{1}{|c|}{ Average Nearest Neighbor Summary } \\
\hline Observed Mean Distance: & 16635.0873 Meters \\
\hline Expected Mean Distance: & 3323.4089 Meters \\
\hline Nearest Neighbor Ratio: & 5.005429 \\
\hline z-score: & 13.272128 \\
\hline p-value: & 0.000000 \\
\hline
\end{tabular}

\begin{tabular}{|r|l|}
\multicolumn{1}{c|}{ Dataset Information } \\
\hline Input Feature Class: & Aiyedade_Main_Markets \\
\hline Distance Method: & EUCLIDEAN \\
\hline Study Area: & 132540561.371384 \\
\hline
\end{tabular}

Figure 2. Results of Average Nearest Neighbour on Distance Travel to Main Market in Ayedaade Local Government Area of Osun State.

5.5. Determinants of Factors affecting Markets Patronized by Traders in the Study Area Factor Analysis was employed to determine most significant factors/ variables influencing the markets patronised by traders in Ayedaade Local Government Area of Osun State. Factor Analysis can be described as a technique to condense data presented in many variables into few variables. It can also be regarded as method of reducing the dimension of data collected into one or more super or principal variables. In the 
interpretation of Factor analysis, variable that has high weight value for a subset of variable is consider as the principal factor (Qualtrics, 2020).

Some of the variables loaded and considered to be factors influencing market patronised include market characteristics (types of goods traded in the market; origin /area or locality where goods brought to the market come from; population of traders who patronise each market). These market characteristics are highly essential because the goods traded in the market will determine the population of traders that patronise a particular market for their business transactions. Also, the centrality or location of the market also plays a significant role in market consideration for sales of goods. Similarly travel characteristics was being considered to be important factors and therefore included in factor analysis (nature of road network connecting villages to the market; Mode of transport accessible to traders and transport fare to the market). Generally, the nature of rural road networks connecting the main market to different communities where traders reside will determine to a large extent whether the market will be considered or patronise by traders for their business transactions or not. Market located on all-weather road may likely attract more traders than the one located on poor rural roads. The types of transport services accessible to traders (walking, motorcycles, pick up), will determine the distance covered, quantity of goods traded to the market as well as the transport fare that may likely be expended on their journey.

Motorcycle is the main mode of public transportation in rural communities in Ayedaade Local Government Area because of the poor connectivity to the main market in the council area. Pick -Up Van is also available in few rural communities and carry an average of 10-12 passengers and operates only on market days. The motorcyclist that operates on all categories of roads in the study area charged exorbitant transport fare on traders as well as good conveyed. This indirectly makes main market less accessible to traders who transverse on long distance from their villages to engage in their business transactions. Similarly the longer the distance travelled to the market, the more the time they are likely to be spent on transit, the less accessible trader is to the market due time wasted on the journey. All these factors mentioned above determine to a large extent on the factors influencing market patronised by traders in the council area. The socioeconomic characteristic of market traders included in factor analysis which is directly related to travel characteristic was the member of household responsible for the movement of goods to the market.

Table $4 \mathrm{a}$ and $4 \mathrm{~b}$ reveal that six factors whose eigenvalue are greater than 1 constituted $65.77 \%$ of the total variance and it is responsible for factors affecting preference of market patronised by traders in the study area. Variables heavily weight loaded on factor 1 is directly related to the types of goods traded in the market that influence the market patronised by traders in the council area (Table $4 \mathrm{~b}$ ). This accounts for about $15.73 \%$ of the total variance (Table $4 \mathrm{a}$ ). The second weight variables that are majorly associated with transport characteristics is the type of road networks connecting sampled villages to the main market that determines the market patronised in the study area. This contributes to about $12.76 \%$ of the total variance (Table $4 \mathrm{a}$ ). Third weight variables relates to the origin of the goods traded in the market $(0.582)$. This Third Factor accounted for $12.34 \%$ of the total variance of the factor influencing markets patronised by traders in the study area. The fourth weight variables loaded on factor 
analysis relates to location of market patronised and the fifth weight variables loaded on Factor analysis is type of market patronised whether periodic or daily market.

Table 4 a: Result of Total Variance Explained of Market Patronized in Ayedaade Local Government Area.

\begin{tabular}{|c|c|c|c|c|c|c|}
\hline \multirow{2}{*}{ Component } & \multicolumn{3}{|c|}{ Initial Eigenvalues } & \multicolumn{3}{|c|}{ Extraction Sums of Squared Loadings } \\
\hline & Total & $\%$ of Variance & Cumulative \% & Total & $\%$ of Variance & Cumulative $\%$ \\
\hline 1 & 2.517 & 15.730 & 15.730 & 2.517 & 15.730 & 15.730 \\
\hline 2 & 2.042 & 12.762 & 28.492 & 2.042 & 12.762 & 28.492 \\
\hline 3 & 1.977 & 12.358 & 40.850 & 1.977 & 12.358 & 40.850 \\
\hline 4 & 1.622 & 10.140 & 50.989 & 1.622 & 10.140 & 50.989 \\
\hline 5 & 1.329 & 8.307 & 59.297 & 1.329 & 8.307 & 59.297 \\
\hline 6 & 1.036 & 6.475 & 65.772 & 1.036 & 6.475 & 65.772 \\
\hline 7 & .952 & 5.949 & 71.721 & & & \\
\hline 8 & .826 & 5.166 & 76.886 & & & \\
\hline 9 & .724 & 4.526 & 81.412 & & & \\
\hline 10 & .653 & 4.080 & 85.492 & & & \\
\hline 11 & .616 & 3.849 & 89.341 & & & \\
\hline 12 & .514 & 3.215 & 92.556 & & & \\
\hline 13 & .429 & 2.683 & 95.239 & & & \\
\hline 14 & .322 & 2.013 & 97.253 & & & \\
\hline 15 & .281 & 1.758 & 99.011 & & & \\
\hline 16 & .158 & .989 & 100.000 & & & \\
\hline
\end{tabular}

Table 4 b: Result of Component Matrix (a) of Market Patronised by Traders in Ayedaade Local Government Area

\begin{tabular}{|c|c|c|c|c|c|c|}
\hline & \multicolumn{6}{|c|}{ Component } \\
\hline & 1 & 2 & 3 & 4 & 5 & 6 \\
\hline Do you have market in your village? & .171 & -.169 & .192 & .514 & .538 & .332 \\
\hline Size (population of the above named market & .478 & -.037 & .415 & .413 & -.167 & .137 \\
\hline Where do most of the traders come from? & .105 & -.397 & .582 & -.191 & -.272 & -.217 \\
\hline Mode of transport to the market & -.010 & -.087 & .276 & .306 & -.518 & .010 \\
\hline Cost of transportation to the market & .319 & .166 & -.173 & .471 & -.336 & -.099 \\
\hline Trip frequency to market & -.347 & -.040 & .316 & -.051 & .290 & -.424 \\
\hline Type of products traded in the market & .550 & -.281 & .505 & -.120 & -.216 & .011 \\
\hline Types of agricultural products mostly traded in the market & .417 & -.441 & .338 & -.344 & .182 & .078 \\
\hline Are these products produced locally (within the LGA & .732 & .421 & -.077 & -.157 & .151 & -.147 \\
\hline Where does the good traded in the market come from & .721 & .241 & -.145 & -.009 & .183 & -.412 \\
\hline Time spent to reach the market patronised & .337 & .375 & -.249 & .186 & -.200 & .341 \\
\hline $\begin{array}{l}\text { Members of household responsible for movement of farm products to the } \\
\text { market }\end{array}$ & .490 & .271 & -.033 & -.491 & .118 & .169 \\
\hline Type of market patronized & .086 & -.157 & .255 & .477 & .516 & .014 \\
\hline Type of road networks connecting your village to the main town & -.226 & .718 & .476 & .118 & .092 & -.243 \\
\hline Condition of road surface & -.223 & .682 & .572 & .037 & -.072 & .035 \\
\hline How often is the road maintained? & -.183 & .295 & .383 & -.396 & .061 & .518 \\
\hline Extraction Method: Principal Comp & & & & & & \\
\hline extra & & & & & & \\
\hline
\end{tabular}

\subsection{Mode of Transportation to Markets in Ayedaade Local Government Area}

More than $70 \%$ of traders especially women relied on public transport services to convey their goods to the market. At a more disaggregate level, not less than $60 \%$ of traders rely on motorcycle for movement of their products to the market in the study 
area. High demand for motorcycle for transportation in the study area had forced many of the traders (women) to book an appointment with motorcyclists ahead of the market day in order to have an opportunity to convey their goods to the market. Approximately $21.3 \%$ of traders indicated that they conveyed their goods to the market by pick-up truck/vans. Table 5 revealed that traders who patronized Odeyinka market used more of pick-up truck or vans as means of the transportation to market. This is because the road connecting the villages to Odeyinka is fairly motorable throughout the whole year compared to some other rural communities in the council area. Less than $10 \%$ of women in the rural communities trekked to markets and travelled several kilometres to engage in commercial activities.

Table 5: Market (s) Patronised and Mode of transportation used to the markets

\begin{tabular}{|c|c|c|c|c|c|c|c|c|c|c|c|c|c|}
\hline \multicolumn{14}{|c|}{ Count } \\
\hline & & \multicolumn{10}{|c|}{ Mode of transport to the market } & \multicolumn{2}{|c|}{ Total } \\
\hline & & \multicolumn{2}{|c|}{ Foot } & \multicolumn{2}{|c|}{ Bicycle } & \multicolumn{2}{|c|}{ Motorcycle } & \multicolumn{2}{|c|}{ Pick-up } & \multicolumn{2}{|c|}{ Car } & & \\
\hline \multirow{4}{*}{$\begin{array}{l}\text { Names of the } \\
\text { market (s) } \\
\text { patronised }\end{array}$} & & No & $\%$ & No & $\%$ & No & $\%$ & No & $\%$ & No & $\%$ & No & $\%$ \\
\hline & ARAROMI & 3 & 20.0 & 1 & 6.7 & 9 & 60.0 & 0 & 0.0 & 2 & 13.3 & 15 & 100 \\
\hline & ODEYINKA & 0 & 0.0 & 0 & 0.0 & 4 & 66.7 & 2 & 33.3 & 0 & 0.0 & 6 & 100 \\
\hline & OLUFI & 10 & 5.5 & 4 & 2.2 & 117 & 64.6 & 41 & 22.7 & 9 & 5.0 & 181 & 100 \\
\hline \multicolumn{2}{|c|}{ Total } & 13 & 6.4 & 5 & 2.5 & 130 & 64.4 & 43 & 21.3 & 11 & 5.4 & 202 & 100 \\
\hline
\end{tabular}

\subsection{Determinant of Variation on Mode Choice of Transportation used to Markets}

Table 6 revealed that the mode of choice of transportation to market vary (Possession of Personal Means of Transport, $\mathrm{F}=1.482<\mathrm{P} .209$; Transport Cost. $\mathrm{F}=7.156<.000$; Market Patronized, $\mathrm{F}=1.037<.389$; Where Goods Traded Come from; $\mathrm{F}=3.722<\mathrm{p} .006$ and Distance from Villages to Market, $\mathrm{F}=1.606,<\mathrm{p} .174)$ across the sampled settlements in the study area. Generally women are less accessible to personal means of transportation. This is because men tend to monopolize transport services available to household member. The distance from villages and types of goods traded in the market depend on the choice of transportation of traders in the area. Even though, motorcycles predominate the transport services available to traders in the study area, many of the traders interacted with claimed that they prefer to use pick - up vans or trucks and Austine diesel vehicle which can carry more passengers and their goods to a reasonable transport fare to the market.

Table 6. Result of Analysis of Variance on Mode Choice of Transportation

\begin{tabular}{|c|c|c|c|c|c|c|}
\hline \multicolumn{7}{|c|}{ ANOVA } \\
\hline & & Sum of Squares & Df & Mean Square & $\mathrm{F}$ & Sig. \\
\hline \multirow{3}{*}{$\begin{array}{l}\text { Do you have personal } \\
\text { means of } \\
\text { transportation? }\end{array}$} & Between Groups & 1.255 & 4 & .314 & 1.482 & .209 \\
\hline & Within Groups & 41.715 & 197 & .212 & & \\
\hline & Total & 42.970 & 201 & & & \\
\hline \multirow{3}{*}{$\begin{array}{l}\text { Cost of transportation to } \\
\text { the market }\end{array}$} & Between Groups & 26.169 & 4 & 6.542 & 7.156 & .000 \\
\hline & Within Groups & 180.108 & 197 & .914 & & \\
\hline & Total & 206.277 & 201 & & & \\
\hline \multirow{3}{*}{$\begin{array}{l}\text { Type of market } \\
\text { patronized }\end{array}$} & Between Groups & .459 & 4 & .115 & 1.037 & .389 \\
\hline & Within Groups & 21.700 & 196 & .111 & & \\
\hline & Total & 22.159 & 200 & & & \\
\hline \multirow{3}{*}{$\begin{array}{l}\text { If no, where does the } \\
\text { good traded in the } \\
\text { market come from? }\end{array}$} & Between Groups & 38.574 & 4 & 9.643 & 3.722 & .006 \\
\hline & Within Groups & 510.362 & 197 & 2.591 & & \\
\hline & Total & 548.936 & 201 & & & \\
\hline If no what is the & Between Groups & 2.912 & 4 & .728 & 1.606 & .174 \\
\hline
\end{tabular}




\begin{tabular}{lllll}
\hline $\begin{array}{l}\text { distance of market(s) } \\
\text { patronised to your } \\
\text { village? }\end{array}$ & Within Groups & 89.271 & 197 & .453 \\
\cline { 2 - 5 } & Total & 92.183 & 201 & \\
\hline
\end{tabular}

\subsection{Transport Fare to Market in Ayedaade Local Government.}

The transport fare to market in Ayedaade Local Government Area of Osun State must be interpreted with caution. This is because majority of public transport operators charge freight carried separately from the trader hiring the vehicle. In actual fact, the public transport operators charge transport fare based on the quantity of goods and distance travelled to the market. Table 7 revealed that $13.4 \%$ of traders claimed that they do not pay any transport fare to and from the market. This category of market women are petty traders who trek from their villages to the markets to engage in their business transactions. Majority of these traders come from Mokore, Mojapa and Wakajaiye villages. Further analysis revealed that $20.8 \%$ of traders spend less than 100.00 on transport fare to the market. This is equivalent to 0.52 USD on transport fare on journey to the market. Table 7 further revealed that $30.7 \%$ of traders spend more

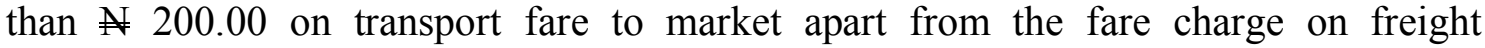
conveyed to the market. This implies that this category of traders spent an average of 1.04 USD on transport fare on their return journey to market. This transport fare charge by public transport operators can be regarded to be too outrageous considering the distance travelled, quantity of goods carried in the council area as well as the economic situation in Nigeria where more than $70 \%$ of their population earned below 1.90 USD per day to move above the poverty line as stipulated by the United State of America (World Bank, 2014; Ferreira; Jolliffe; Prydz, 2015). Interaction with some traders revealed that some of the commercial transport operators use the advantage nonavailability of community based transport services to charge exorbitant transport fares at the detriment of traders in the study area. A large proportion of these traders come principally from Loode, Sare, Sewe and Mojapa villages. However, in a study carried out on the evaluation of the profitability and performance of cashew nut marketing in Ankpa Local Government Area of Kogi State, Adejo; Adejo; Zakari (2018: p. 53) have identified low transport fare to convey agricultural produce to the market as an important variable cost that increase the profit margin/ positive gross margin of traders in their study area. It can therefore be inferred that if transport fare charge by public transport operators in Ayedaade Local Government Area of Osun State is reduce to the lowest minimum, it will increase the profitability of trading activities in the region.

Table 7. Transport Fare to the Markets in the Study Area

\begin{tabular}{|c|c|c|c|c|c|c|c|c|c|c|}
\hline \multicolumn{11}{|l|}{ Count } \\
\hline & \multicolumn{8}{|c|}{ Cost of transportation to the market } & \multirow{2}{*}{\multicolumn{2}{|c|}{ Total }} \\
\hline & \multicolumn{2}{|c|}{ None } & \multicolumn{2}{|c|}{ Less than $\$ 100$} & \multicolumn{2}{|c|}{$\$ 100-\$ 200$} & \multicolumn{2}{|c|}{ More than $¥ 200$} & & \\
\hline Name of Settlement or village & No & $\%$ & No & $\%$ & No & $\%$ & No & $\%$ & No & $\%$ \\
\hline AKIRIBOT & 2 & 7.4 & 5 & 11.9 & 8 & 11.3 & 0 & 0.0 & 15 & 100.0 \\
\hline ALABE PA & 1 & 3.7 & 0 & 0.0 & 9 & 12.7 & 5 & 8.1 & 15 & 100.0 \\
\hline BENBE & 0 & 0.0 & 1 & 2.4 & 12 & 16.9 & 1 & 1.6 & 14 & 100.0 \\
\hline LAGBAKA & 1 & 3.7 & 1 & 2.4 & 8 & 11.3 & 6 & 9.7 & 16 & 100.0 \\
\hline LOODE & 1 & 3.7 & 2 & 4.8 & 0 & 0.0 & 13 & 21.0 & 16 & 100.0 \\
\hline MOJAPA & 5 & 18.5 & 2 & 4.8 & 0 & 0.0 & 10 & 16.1 & 17 & 100.0 \\
\hline MOKORE & 5 & 18.5 & 9 & 21.4 & 1 & 1.4 & 0 & 0.0 & 15 & 100.0 \\
\hline OGBAAGA & 0 & 0.0 & 2 & 4.8 & 13 & 8.3 & 0 & 0.0 & 15 & 100.0 \\
\hline
\end{tabular}


Published by Hasanuddin University and Asian Rural Sociology Association

\begin{tabular}{|c|c|c|c|c|c|c|c|c|c|c|}
\hline OLOBA & 0 & 0.0 & 7 & 16.7 & 5 & 7.0 & 4 & 6.4 & 16 & 100.0 \\
\hline OLUWADA & 3 & 11.1 & 8 & 19.0 & 6 & 8.4 & 0 & 0.0 & 17 & 100.0 \\
\hline SARE & 0 & 0.0 & 1 & 2.4 & 2 & 2.8 & 12 & 19.5 & 15 & 100.0 \\
\hline SEWE & 5 & 18.5 & 0 & 0.0 & 0 & 0.0 & 11 & 17.7 & 16 & 100.0 \\
\hline WAKAJAYE & 4 & 14.8 & 4 & 9.5 & 7 & 9.9 & 0 & 0.0 & 15 & 100.0 \\
\hline Total & 27 & 13.4 & 42 & 20.8 & 71 & 35.1 & 62 & 30.7 & 202 & 100.0 \\
\hline
\end{tabular}

\section{Conclusion}

This study examined travel characteristics of women to markets in some rural communities in Ayedaade Local Government Area of Osun State. The research present or expose the challenges encountered by traders on transit during their business transactions so that the stake holders can provide urgent attention in order to achieve sustainable rural development in the region. Primary and secondary data were utilised for the study. Descriptive statistics such as table of percentages and cross tabulation were used to explain market characteristics and traders travel patterns. Factor Analysis was used to determine the principal or main heavily weighted variables affecting market preference or patronized by traders for their business transactions. Findings revealed that traders trekked long distances to the market and women relied more on motorcycles for their trips. Public transport operator's charges indiscriminate fare for movement of freight to the market. Olufi market is the main periodic market patronized by traders in the council area because of distance and varieties of goods traded in the market. The study recommends that some of the dead markets in the study area should be refertilised or encouraged and possibly provided with well linked transport infrastructure in order to promote rural development in the region. The study concludes that there is need to provide community based transport services particularly motorcycle that constitutes the main mode of transportation in the study area at subsidized rate for rural communities in Nigeria. This will enhance the accessibility of women to markets and participate in order productive activities in the rural areas of Nigeria.

\section{References}

Adejo, P.E; Adejo, E.G; Zakari, J. 2018. Evaluation of the Profitability and Performance of Youth Participation in Cashew Nut (Anacardium Occidentale) Marketing in Ankpa Local Government Area of Kogi State, Nigeria. Journal of Asian Rural Studies, 2(1):49- 56.

Adetunji, M. A. 2003. Geographical Analysis of Rural Transport and Accessibility in Ayeedaade Local Government Area of Osun State. Unpublished M.Sc. Thesis, Submitted to The Department of Geography, Obafemi Awolowo University, IleIfe.

Adetunji M. A., Aloba, O. 2018. Analysis of the Distribution Pattern and Accessibility of Students to Secondary Educational Facilities in Lokoja, Kogi State, Nigeria. Journal of Analele Universităţii din Oradea -Seria Geografie, XXVIII (1): 113124.

Astrop, A.; Palmer, C.; Maunder, D. and Babu, D. M. 1996. The Urban Travel Behaviour and Constraints of Low Income Households and Females in Pune, India. National Conference on Women's Travel Issues, Baltimore, Maryland, USA, 23-26 October 1996. Transport Research Laboratory, 
Crowthorne Berkshire United Kingdom. Working Paper PA3206/96. Available at: https://pdfs.semanticscholar.org/b1dc/ef38529ddc2463370cb6 17bc075bc7b98462.pdf

Cui, M., Levinson, D. 2018. Full cost accessibility. The Journal of Transport and Land Use, 11 (1): 661-679'

Dawson, J; Barwell, I. 1993. Roads Are Not Enough: New Perspectives on Rural Transport Planning in Developing Countries: Intermediate Publication, London, 1993. Available on: https://www.scirp.org/reference/ReferencesPapers.aspx?ReferenceID=977175

Deike, P. 2013. Gender and Sustainable Urban Mobility. Thematic Study Prepared for Global Report on Human Settlements 2013 Also available at: https://unhabitat.org/wpcontent/uploads/2013/06/GRHS.2013.Thematic.Gender.pdf

Dey, T; Pathak, A.K; Baghmar, N.K. 2017. Geospatial Analysis of Rural Weekly Markets: A Case Study of Bametara District of Chhattisgarh, India. Journal of Humanities And Social Science (IOSR-JHSS) Volume 22, Issue 5 Ver.II(May 2017),pp.45-53.

https://pdfs.semanticscholar.org/407e/5b660a33e3b1ef64315c6b760361d7436a5 e. $\quad$ pdf

Donnges, C. 2001. Rural Transport and Local Government Units: How to improve Rural Transport for the Rural Poor. Senior Developing Planner, ILO Regional Office, Bangkok, Thailand, Transport and communications Bulletin for Asia and the Pacific No 71, pp. 19-27. Also available at: https://www.ilo.org/wcmsp5/groups/public/--- asia/---robangkok/documents/publication/wcms 100025.pdf

Ejembi, S. A; Obekpa, H. O; Ivande, P. O. 2017. Perception of Gender Issues on Agricultural Resources Management Among Dwellers in Benue State, Nigeria. Journal of Asian Rural Studies, 1(2): 145-151

Ellis, S.D. (1997). Key issues in Rural Transport in Developing Countries Transport 260 Growthorne: TRL. Also Available at:http://agris.fao.org/agrissearch/search.do?recordID $=$ GB1997039687

Exchange Rate UK, 2006-2020. Live Dollar to Nigerian Naira Exchange Rate (USD/NGN) Today. Available online at: https://www.exchangerates.org.uk/Dollars-to-Nigerian-Naira- currencyconversion-page.html

Filani, M.O. (1993). Transport and Rural Development in Nigeria. London: Bulter Work Heinemann Ltd.

Hermann,P.G. Schneider .2007. Issues relating to quality of life in Postmenopausal women and their measurement in Treatment of Postmenopausal women Third Edition, 2007

Limi Atsushi, Ahmed Farhad, Anderson Edward Charlse Diehl Adam Stone, Maiyo

Leban, Peralta-Quiros Tatiana and Rao Kulwinder Singh(2016). New Rural Access Index: Main Determinants and Correlation Policy. Policy Research Working Paper 7876. World Bank Group, Transport and ICT Global Group, pp 1-16 . Available at: http://documents.worldbank.org/curated/en/821621478094511356/pdf/WPS7 876.pdf 
Ferreira, F., Jolliffe; D.M., Prydz, E. B. 2015 . The international poverty line has just been raised to $\$ 1.90$ a day, but global poverty is basically unchanged. How is that even possible?. World Bank Group. Available online at: https://blogs.worldbank.org/developmenttalk/international-poverty-line- hasjust-been-raised-190-day-global-poverty-basically-unchanged-how- even

Layonu, A. Akinwumi, S. 2002. Ayedaade Government and People, Ibadan: Laytal Communications Consultants Press Ibadan.

Pucher, J. (2009). Cycling and walking for all New Yorkers: path to improved public health, Key note address for Fit City Conference, 8 June, New york

Rural Urban Marketing Linkages FAO http://www.fao.org/3/a0159e/A0159E03.htm

Tracey-White, J.D. 1995. Retail markets planning guide. FAO, AGRICULTURAL SERVICES BULLETIN 121. Available online at: http://www.fao.org/3/V8390E/V8390E00.htm\#Contents

World Bank 2014. World Bank on poverty in Nigeria. Poverty and Transportation: A way forward 